Chapman University

Chapman University Digital Commons

Film Studies (MA) Theses

Dissertations and Theses

Spring 4-15-2019

\title{
Stardom, Spectacle, Show, and Salability: United Artists and the Founding of the Hollywood Blockbuster Model
}

Jessica Johnson

Chapman University, johns284@mail.chapman.edu

Follow this and additional works at: https://digitalcommons.chapman.edu/film_studies_theses

Part of the Other Film and Media Studies Commons

\section{Recommended Citation}

Johnson, Jessica. "Stardom, Spectacle, Show, and Salability: United Artists and the Founding of the Hollywood Blockbuster Model." Master's thesis, Chapman University, 2019. https://doi.org/10.36837/ chapman.000051

This Thesis is brought to you for free and open access by the Dissertations and Theses at Chapman University Digital Commons. It has been accepted for inclusion in Film Studies (MA) Theses by an authorized administrator of Chapman University Digital Commons. For more information, please contact laughtin@chapman.edu. 
Stardom, Spectacle, Show, and Salability:

United Artists and the Founding of the Hollywood Blockbuster Model

A Thesis by

Jessica J. Johnson

Chapman University

Orange, California

Dodge College of Film and Media Arts

Submitted in partial fulfillment of the requirements for the degree of

Master of Arts in Film Studies

May 2019

Committee in charge:

Emily Carman, Ph.D., Chair

Luci Marzola, Ph.D.

Dawn Fratini, CPhil, MFA 
The thesis of Jessica J. Johnson is approved.
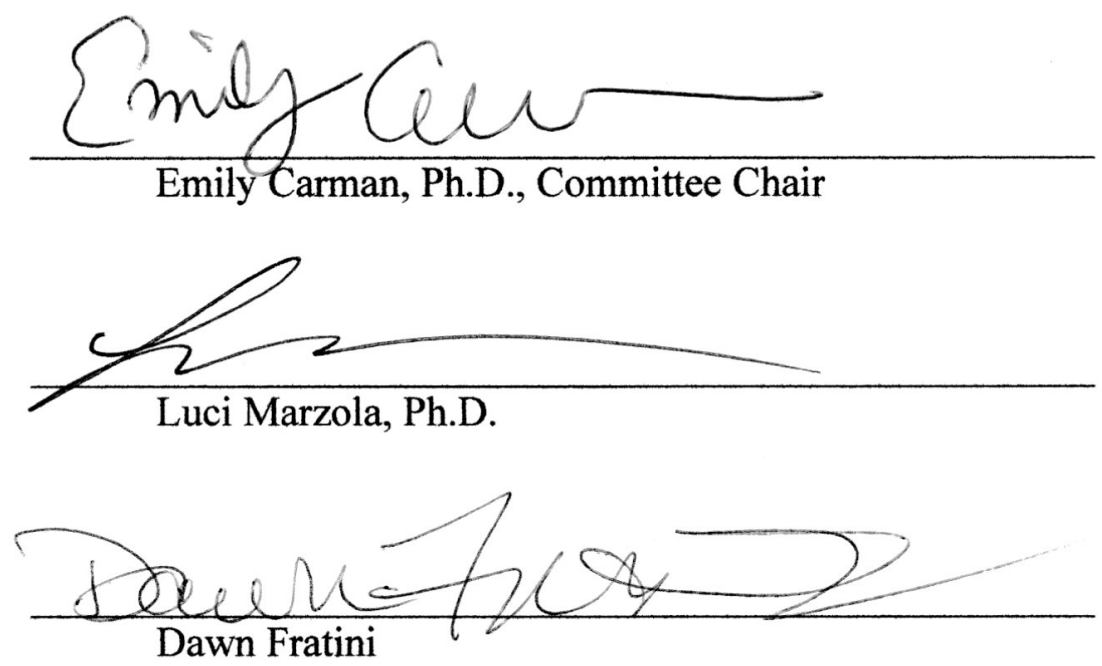

May 2019 
Stardom, Spectacle, Show, and Salability:

United Artists and the Founding of the Hollywood Blockbuster Model

Copyright (C) 2019

by Jessica J. Johnson 


\section{ACKNOWLEDGEMENTS}

I would first like to express my deepest appreciation to my thesis advisor Dr. Emily Carman, whose tremendous knowledge and passion for Hollywood history was nothing less than true inspiration. Without her continuous support of my topic of study and research, guidance, enthusiasm, and constant encouragement, this thesis would not have been possible. I would also like to thank my committee members, Professor Dawn Fratini and Dr. Luci Marzola for their encouragement, support, and insightful feedback.

I further wish to acknowledge Elaina Friedrichsen for the opportunity to work closely with as an assistant archivist intern with the Mary Pickford Foundation, as well as Marc Wanamaker and Cari Beauchamp for their inspiring love of film history and willingness to share their wealth of knowledge. I would also like to thank the teams of archivists at the Margaret Herrick Library, the New York Public Library, and the Museum of Modern Art, whose assistance during my research was paramount to this thesis.

I must express my profound gratitude to my parents, Gene and Christine, for their constant and continued support in all of my wild ambitions. I truly could not have done it without you.

Finally, I end with thanking the four individuals who form the subject of this thesis - Mary Pickford, Douglas Fairbanks, Charlie Chaplin, and D.W. Griffith. These four brave and truly creative individuals shaped Hollywood as we know it, and their actions helped incite my love of the cinematic medium. 


\begin{abstract}
Stardom, Spectacle, Show, and Salability:

United Artists and the Founding of the Hollywood Blockbuster Model by Jessica J. Johnson
\end{abstract}

United Artists was an independent film distribution company that Douglas Fairbanks, Charlie Chaplin, D.W. Griffith, and Mary Pickford jointly formed in 1919 to maintain creative autonomy over their work. Without the benefit of block booking practices through studio-owned theater houses, each founding artist established specific economic and aesthetic practices within their respective oeuvres in order to maintain company solvency. The resulting films produced during the company's formative years (1919-1931) saw increased emphasis and innovation in regard to stardom, spectacle, show, and salability, features which ultimately innovated the model for the contemporary Hollywood blockbuster. Attributing the formation of the blockbuster to United Artists not only complicates the notion of the Hollywood blockbuster as a post-World War II phenomenon, but also broadens our comprehension of blockbuster filmmaking by formulating a model in which one can refine blockbuster criteria. This reframes the blockbuster as the cornerstone of the Hollywood film industry for over a century and presents it as a more persistent phenomenon. 


\section{TABLE OF CONTENTS}

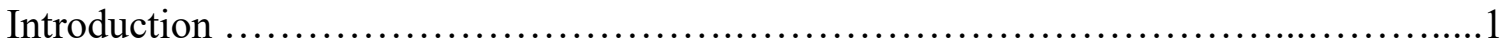

Defining the Blockbuster.....................................................

Douglas Fairbanks: Spectacle \& Salability.........................................12

Charlie Chaplin: Stardom \& Spectacle.........................................18

D.W. Griffith: Show \& Spectacle.............................................. 22

Mary Pickford: Salability \& Stardom.........................................27

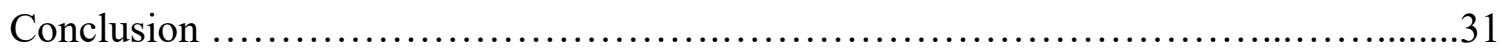

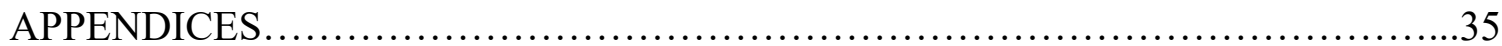

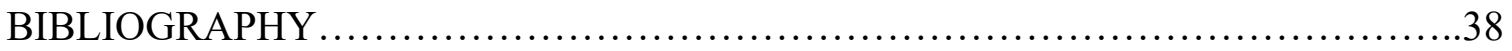




\section{$\underline{\text { Introduction }}$}

In a press book released to exhibitors for the 1921 release of The Three Musketeers, one can find descriptors that might be mistaken for promotional materials for the latest box office-dominating film: "The most gripping and spectacular film ever produced;" "A picture with universal appeal;" "One of the most painstaking and elaborate efforts of picture making of the year;" "A feature attraction;" "This feature is said to embody more that is adventurous, romantic and dramatic than it has ever before been possible to incorporate into a film vehicle;" "A lavish presentation;" "No more vivid and picturesque tale has ever been presented on the screen than this." ${ }^{1}$ These commendations are, however, focused instead on what is nearly a century-old film. The Three Musketeers was among the first films to be produced and distributed by the United Artists independent film corporation (hereafter UA), which at the time had only been in operation for two years. The aforementioned descriptors were specifically penned to sell this film to eager moviegoing fans, describing exclusive behind the scenes details, the inner workings of the set, the film's many merits, and never-before-seen thrills. Though the Hollywood film industry has changed drastically in the past century, the words within this press book reveal an apparent synergy between past and present. As with many of the other UA films produced by Fairbanks and his fellow founding artists Mary Pickford, D.W. Griffith, and Charlie Chaplin, The Three Musketeers was intentionally branded as a significant, spectacular event from the moment of its inception in order to reach a widespread audience and amass substantial financial returns, and therefore is but one

\footnotetext{
${ }^{1}$ Oversized red striped press book, The Three Musketeers Production Files. Margaret Herrick Library.
} 
example of what would ultimately incite significant change in the Hollywood film industry.

UA was a distribution company that Hollywood luminaries Douglas Fairbanks, Charlie Chaplin, D.W. Griffith, and Mary Pickford jointly formed in 1919 for the sake of protecting their salability not only as stars and producers, but as independent artists. Separation from the other major Hollywood studio behemoths of the era ensured the artists' total creative autonomy over their work, yet hindered their assurances of gaining widespread distribution without the benefit of studio-owned theater houses. In order to maintain continued solvency, it was necessary for each artist to establish specific economic and aesthetic practices, and harness their own caliber of celebrity, status, artistry, and innovation to create pictures that would gain a profit without the benefit of their rival studios' process of vertical integration. The resulting films produced during UA's formative years saw emphasis on stardom, spectacle, show, and salability, thereby forming not only early examples of Hollywood blockbuster filmmaking, but also innovative practices to further the development of the contemporary Hollywood blockbuster model as a whole.

UA's historical significance has been well documented by scholars, most notably Tino Balio in his two books United Artists: The Company Built by the Stars and United Artists: The Company that Changed the Film Industry. Balio's primary focus is analyzing the struggles UA endured and illuminating its history after the decline of the studio system post-World War II, wherein the other major studios adopted UA's example in 
distributing and financing independent productions. ${ }^{2}$ Despite his research being inarguably the most thorough survey on the history of the company, this thesis serves as an expansion of Balio's work. By utilizing primary materials from the special collections of the Margaret Herrick Library, New York Public Library, the Museum of Modern Art, and the Mary Pickford Foundation archives, I elucidate the specific tactics used by the founding artists to reveal both their economic and aesthetic innovations, and how these practices furthered the development of the blockbuster. In contrast to other major studios whose archives are not as comprehensive, utilizing UA as the foundation of this research was optimal due to the celebrity nature of the core founders and that their histories are so well preserved in various archives around the world. Glimpses into their lives, ideas, business practices, and frustrations are evidenced in their personal papers in archival collections in many locations both locally and internationally. Some of these collections were accessed, and supporting materials were included in this thesis for the purpose of substantiating motivations, struggles, and intentions of these four individuals, whose uniting was crucial to the success of UA. While this thesis unites studies of stardom, genre theory, and industry studies in embryonic form, future development of this model would necessitate additional research including accessing the Chaplin archives at Montreaux, Switzerland or the Cineteca di Bologna, and the United Artists Collection at

\footnotetext{
${ }^{2}$ See Tino Balio, United Artists: The Company That Changed the Film Industry,. (Madison: University of Wisconsin Press, 1987), 6. Balio credits UA's later business model, developed by Arthur Krim and Robert S. Benjamin in 1951, as having foregrounded the economic practices of Hollywood commercial cinema today, writing "the history of UA is, in essence, the history of a main line of development in the contemporary American film industry." This came as a result of the anti-trust verdict that accompanied the Paramount Decrees of 1948, wherein the other major studios shifted to adopt UA's distribution model.
} 
the Wisconsin Center for Film and Theater Research, in addition to comparisons with other studio records of the era to conclusively establish UA as unique.

This thesis complicates the stance that the blockbuster is solely a postwar phenomenon, and instead asserts it as a conception that is as old as the practice of commercial filmmaking itself. ${ }^{3}$ Although there are films from previous studios that precede or coincide with UA's development that have been labelled as "features," “epics," “super-spectacles," such as Societa Italiana Cines' Quo Vadis (Guazonni, 1913), Paramount's Treasure Island (Tourneur, 1920), or Universal's The Phantom of the Opera (Julian, 1925), UA is distinct in that the blockbuster is central to its initial development as an independent studio in order to maintain solvency. ${ }^{4}$ Whereas its competitors could complement their larger, epic films with smaller, low-budget content (later known as " $\mathrm{B}$ movies"), UA was the first of the major established Hollywood studios to embrace the blockbuster to such an extent, doing so from the onset of their corporation's founding in 1919. Therefore, the historical scope of this thesis examines the first twelve years of UA's operation (1919-1931) when Fairbanks, Chaplin, Griffith, and Pickford were all concurrently producing content.

I contest the notion offered by Julian Stringer in his book Movie Blockbusters that a blockbuster is an undefinable genre without any essential characteristics. ${ }^{5}$ Rather than

\footnotetext{
${ }^{3}$ See Thomas Schatz, "The New Hollywood (1993)" in Movie Blockbusters ed. Julian Stringer, (New York: Routledge, 2003), 19, Justin Wyatt, High Concept: Movies and Marketing in Hollywood (Austin: University of Texas Press, 1994), 67, and Charles R. Acland, "Senses of Success and the Rise of the Blockbuster," Film History: An International Journal 25, no. 1-2 (2013): 11-18.

${ }^{4}$ See Stuart Hall and Steve Neale. Epics, Spectacles and Blockbusters, (Detroit: Wayne State University Press, 2010).

5 Julian Stringer, "Introduction," in Movie Blockbusters ed. Julian Stringer, (New York: Routledge, 2003), 42.
} 
accepting it as a constantly-evolving genre, this thesis reframes the blockbuster as a phenomenon with four key attributes based on the aggregation of defining terms from established blockbuster scholars: Stardom, Spectacle, Show, and Salability, which form the basis of my blockbuster model. ${ }^{6}$ Stardom applies to the ways in which the film was cast and what specific power individuals involved with the creative team have in the selling of their film. Spectacle examines the size and overall scope of the film, including production value, budget, running time, and special effects. Show relates to how the film is distributed, exhibited, and the degree to which it is treated as an "event." Finally, Salability remains the most crucial element to this model, as a blockbuster is intentionally marketed and designed to reach the largest audience possible with the intention to gross the largest amount of financial returns.

Salability was crucial to UA's development as well, the company's original mission statement advocating for the protection and improvement of the film industry via film marketing. ${ }^{7}$ This, along with several other key actions needed to keep the struggling company aloft during its first few years, forced UA to embrace new tactics to make their films as marketable as possible in order to garner a profit. Douglas Fairbanks's complete transformation as an action star predicated his films' success as early blockbusters, contributing to both Spectacle and Salability through his highly marketable genre films that featured the latest technology and were primarily based on well-known literature that showcased astounding physical action and special effects. Charlie Chaplin harnessed

${ }^{6}$ Capitalized here to illustrate categories.

${ }^{7}$ Certificate of Incorporation of United Artists Corporation, 2/25/1919, Mary Pickford and the United Artists Corporation legal material, Box 1, folder 1, Margaret Herrick Library. 
Stardom, using his well-beloved and highly salable Tramp persona to experiment with spectacular gags and innovative effects. Though his popularity was waning, D.W. Griffith offered innovations in Show, making his films financially competitive with the biggest stage productions and creating an enticing, themed environment surrounding his works' releases. Finally, Mary Pickford's business acumen was foundational to both Stardom and Salability, as she harnessed and cultivated her personal brand to sell her own image as much as that of her films. As UA was not afforded the same securities as vertically integrated studios, these actions worked not only to allow the production of their independent features, but also established an early foundation to what we recognize as the contemporary Hollywood blockbuster model. Thus, this thesis problematizes the pervasive trend of periodization that largely informs the way in which film history is recorded, and broadens our comprehension of blockbuster filmmaking by formulating a model by which one can refine blockbuster criteria.

Defining the Blockbuster

In his seminal 1993 essay "The New Hollywood," Thomas Schatz provides a framework for defining a Hollywood blockbuster, interspersing various descriptors throughout his work such as state-of-the-art-production values, featuring top stars, plotdriven, visceral, kinetic, fast-paced, reliant on special effects, fantastic, targeted at younger audiences, and having a national promotion-and-release campaign. ${ }^{8}$ Though invaluable, these attributes are featured for the sole purpose of differentiating Schatz' conceptualization of blockbuster cinema from non-blockbuster cinema, rather than

8 Thomas Schatz, "The New Hollywood," in Movie Blockbusters, ed. Julian Stringer, (New York: Routledge, 2003), 18-29. 
explicitly stating a succinct definition. Since Schatz's work, an overwhelming majority of scholarship on the blockbuster similarly offers potential criteria, though explicitly states outright the protean nature of the term. ${ }^{9}$ Others avoid it altogether, such as Tom Shone (2004) whose uncommitted definition labels it as "not quite a genre, but almost; often science fiction but not necessarily; something to do with action movies although not always." 10

Indeed, the blockbuster is "not quite a genre," as it is not merely a means of categorizing a film but is instead something infinitely more nuanced. ${ }^{11}$ Studies of genre in the recent past have proven problematic within the media studies field as, much like the blockbuster, there remains a disconnect between multi-dimensional distinctions of what a "genre" truly is and how it is constructed. ${ }^{12}$ In lieu of genre, I translate James Naremore's reassessment of film noir to my own study of the blockbuster, considering it a "discursive phenomenon $[\ldots]$ that helps to shape commercial strategies and aesthetic ideologies." ${ }^{\prime 13}$

${ }^{9}$ See Geoff King, Spectacular Narratives: Hollywood in the Age of the Blockbuster, (New York: Tauris Publishers, 2000), 8, who labelled them a "marriage between spectacle and narrative," while Anita Elberse, Blockbusters: Hit-Making, Risk-Taking, and the Big Business of Entertainment, (New York: Henry Holy and Company Publishers, 2013), 19, referred to them as "big-budget productions aimed at large audiences," or Bob Rehak, "2003: Movies, 'Shock and Awe,' and the Troubled Blockbuster," in American Cinema of the 2000s: Themes and Variations ed. Timothy Corrigan, (New Brunswick: Rutgers University Press, 2012), 90, who attributes specific values to his criteria, boldly stating that by contemporary standards, a movie "must exceed $\$ 100$ million in ticket sales" in order to be considered a blockbuster. ${ }^{10}$ Tom Shone, Blockbuster: How Hollywood Learned to Stop Worrying and Love the Summer, (New York: Free Press, 2004), 28.

${ }^{11}$ Ibid.

${ }^{12}$ See Steve Neale, Genre and Hollywood, (London: Routledge, 2000) 28. Neale here makes the case that one must instead think of genres "as ubiquitous, multifaceted phenomena rather than as one-dimensional entities to be found only within the realms of Hollywood cinema or of commercial popular culture.

${ }^{13}$ James Naremore, More than Night: Film Noir in Its Contexts, (Berkeley: University of California Press, 2008), 11. 
This therefore activates the term "blockbuster" as something that has the power to create ongoing industrial standards, rather than the passivity of a mere genre label. When considering it a discursive phenomenon, the commercial strategies and aesthetic ideologies that Naremore presents form the central crux upon which all other vacillating attempts to define a blockbuster can be contextualized.

There are consequently four essential qualities that I delineate and list here in order of importance: Salability, Spectacle, Show, and Stardom. These four tenets encompass the lifespan of a movie, from the moment of its inception through its ultimate release, each contributing specific characteristics that recur in blockbuster cinema. Although to be a blockbuster a film must display some aspect of each of these categories, they are not mutually exclusive, as some criteria cross over into numerous fields [Appendix A]. A wide array of scholarship from film experts and analysts and the various characteristics they use to describe the "blockbuster mentality" illustrates instances of repetition to discern which features hold more value than others. The resultant definition is derived from these assessments and, for the sake of clarity, I have distilled these descriptors down to four identifying traits._Only with these defining traits is it possible to discern a precise definition of blockbuster: a high-budgeted film with an emphasis on visual spectacle that is intentionally designed, marketed, and exhibited to reach the largest audience imaginable in order to amass the largest amount of income.

Stardom refers to a highly recognizable public figure featured in a role on a project that will garner greater attention due to their established fame. Often the inclusion of a celebrity accompanies a high level of cost, and the more stars a film contains, the more attractive it will be to a wider demographic. Stardom directly influences a 
blockbuster's salability, as a star's recognizability and fandom becomes an attractant to lure viewers into theaters. The star image also informs elements of marketing, such as promotional material (including interviews, posters, trailers, and advertisements) and merchandising associated with the film in question (such as toys, clothing, and memorabilia). ${ }^{14}$

Spectacle as a whole accompanies an idea of expansiveness in terms of how the blockbuster presents its story and its visual dynamics on screen. Since the silent era, "spectacle" was used as a term to largely refer to spectacular displays of action, settings, and scenes in film. ${ }^{15}$ Spectacle includes a large budget, a massive cast, scale of production value including on-location shooting, large, elaborate sets, and special effects. More often than not, this accompanies a display of new technological innovations, a cutting-edge entry into the world of "new" or "never before seen" techniques that can therein serve as selling points. ${ }^{16}$ This further works to sell such a film as an unmissable "event" that one must see in a particular venue in order to experience this new utilization of technology to the fullest, some of these technologies including sound, color, screen dimension, image resolution quality, and special cases such as 3-D, 4-D, and motion theaters.

The third category, Show, features a specific release plan oriented around the blockbuster, which specifically refers to a process by which a film is shown. In the first half of the twentieth century, road-showing was utilized to circulate nonstandard,

\footnotetext{
${ }^{14}$ See Justin Wyatt, High Concept: Movies and Marketing in Hollywood, (Austin: University of Texas Press, 1994), 31-37.

${ }^{15}$ Hall and Neale, Epics, Spectacles and Blockbusters, 5.

16 Allen, "Talking about a revolution," 101.
} 
multireel films first in large cities, used to generate publicity and word of mouth. ${ }^{17}$ Wide releases, on the other hand, refer to films that open simultaneously in hundreds of theaters. ${ }^{18}$ This also, with few exceptions, means incorporating a seasonal release plan, which is usually catered to audiences during the summer or winter months, often indicating a film's specific targeting of a particular audience demographic. ${ }^{19}$

Trailers, print ads, merchandise, star-centered promotions, an emphasis on the new and spectacular, genre-based audience targeting, particular release dates, and the labelling of the film as "an event" all inform the last remaining category, Salability. The consideration of a film's salability is paramount to its blockbuster status, and therefore has an indelible impact on the model in a variety of ways. Branding strategies further aid in the selling of a film, creating symbiotic partnerships with brand labels and corporate conglomerates via product placement and cross-promotional material in order to attract "everybody." ${ }^{20}$ The criteria all of these categories share is marketing, which remains essential to the core definition of a blockbuster, as the very intention of such a film is to make the most amount of financial revenue possible. This is only accomplished through the proper publicity of the most recognizable, salable, and spectacular elements of the film, as well as what star power is associated and how the attendance of the film will emulate a must-see "show" experience.

${ }^{17}$ Steve Neale, "Hollywood Blockbusters: Historical Dimensions" in Movie Blockbusters ed. Julian Stringer, (New York: Routledge, 2003), 52.

${ }^{18}$ Today, a wide release is considered a to debut on 600 or more screens. Box Office Mojo, "Box Office Tracking By Time," Accessed January 16, 2019. https://www.boxofficemojo.com/about/boxoffice.htm ${ }^{19}$ Tom Shone, Blockbuster: How Hollywood Learned to Stop Worrying and Love the Summer, 1-20.

${ }^{20}$ Paul Grainge, Brand Hollywood: Selling entertainment in a global media age, (London: Routledge, 2008), 134. 
The aforementioned blockbuster model has precedent within UA's original Certificate of Incorporation, wherein Griffith, Chaplin, Fairbanks, Pickford, and Hiram Abrams, the head of the company at the time, presented three statements of purpose:

a) To acquire, produce, create, sell, lease, market or dispose of pictures, play and photoplays, and any and all rights and interests therein or in regard thereto and all other articles connected therewith or incidental thereto.

b) To improve the photoplay industry and its artistic standards, and the methods of marketing photoplays.

c) To market photoplays in the interest of artists who create them. ${ }^{21}$

UA's foremost tenets are here established as creative autonomy, improving the film industry, and controlling how their films are marketed, distributed, and screened. The unification of these four founding artists in particular, each of them having amassed an incredible amount of acclaim and success independent from one another, resulted in the forming of a company that had to adapt to remain competitive, rejecting a tried-and-true Hollywood model in favor of creative autonomy: D.W. Griffith, who prior to joining UA had made two of the largest spectacle epic films produced in the 1910s, The Birth of a Nation (1915) and Intolerance (1916); Mary Pickford, “America's Sweetheart," an actress and bonafide superstar whose iconic "waif" roles made her an international household name resulting in widespread fame and her increased confidence to control her own business affairs soon afterwards; Douglas Fairbanks, Pickford's future husband and a skilled performer and star in his own right in both comedy and spectacular action films; Charlie Chaplin, an internationally known comic sensation whose "Tramp" films made him one of the most famous motion picture stars in the world at the time. Together, the

${ }^{21}$ Certificate of Incorporation of United Artists Corporation, 2/25/1919, Mary Pickford and the United Artists Corporation legal material, Box 1, folder 1, Margaret Herrick Library. 
four would produce over sixty films for UA, many of which continued to see large financial returns that rendered them amongst the highest grossing films of their respective release years. ${ }^{22}$ Of the four, Pickford and Fairbanks' joint dedication to the company's development and the advancement of their personal brands were paramount in furthering the blockbuster, whereas Chaplin and Griffith function as secondary albeit looming influences. In the formative period of UA's first twelve years from 1919 to 1931, nearly sixty percent of the total number of films produced can be considered blockbusters in how they utilize elements of Show, Stardom, Spectacle, and Salability [Appendix B], determined by analyzing the artists' star personae, the production elements that were emphasized over others, and the means in which their films were marketed and exhibited. The results demonstrate that although some founders had more emphasis in particular categories than others, their inaugural actions during this foundational period of UA defined what would become known as the blockbuster approach.

Douglas Fairbanks: Spectacle \& Salability

Douglas Fairbanks' dedication to exploring new trends and technologies is at the core of his contributions to the blockbuster during his time with UA, designating him as the foremost contributor to innovations that influenced the blockbuster model. He further used his newfound potential for creative control via UA to break free of his prior romantic comedy roles in favor of an action hero persona that ultimately would become his cinematic legacy. His primary contribution to the blockbuster model is in the producing of his action-adventure films, a genre that has traditionally dominated the blockbuster market due to its high level of spectacle and marketability to a diverse

${ }^{22}$ Balio, United Artists: The Company Built by the Stars, 43. 
audience demographic. The proliferation of this genre during Fairbanks' early days with UA can be sharply contrasted with that of his comedies of the 1910s, which do not exhibit nearly the same amount of concentrated spectacle as the action features: high budgets, large casts, elaborate sets, astounding action, stunt choreography, and quite simply Fairbanks himself, who is often referenced as the first American action star. ${ }^{23}$

The film that best encompasses all that Fairbanks provides to the blockbuster model is Douglas Fairbanks in Robin Hood (Dwan, 1922). Randy Haberkamp has even referenced this film as being "an early prototype of the movie blockbuster." 24 Many elements of the model can be found within the production of Robin Hood, perhaps the most obvious influence being the Stardom expressed in the title alone. It was copyrighted as Douglas Fairbanks in Robin Hood, thereby cementing the star as an essential, indivisible part of the film's construct. Spectacle, however, was apparent in abundance, London's The Sunday Chronicle having called it "one of the most splendid spectacles ever seen on screen." ${ }^{25}$ Robin Hood had a budget of $\$ 1.4$ million, surpassing that of Griffith's Intolerance, and was shot on the Pickford-Fairbanks Studio lot, where a group of five hundred workmen constructed the film's massive three hundred and ten-foot-tall

\footnotetext{
${ }^{23}$ Tracey Goessel, The First King of Hollywood: The Life of Douglas Fairbanks, (Chicago: Chicago Review Press, 2015), viii.

${ }^{24}$ Randy Haberkamp. Program from Academy of Motion Picture Arts and Sciences screening of Douglas Fairbanks in Robin Hood on Monday, June 27, 2011 at the Samuel Goldwyn Theater, 4. Robin Hood Production Files, Margaret Herrick Library.

${ }^{25}$ Ralph Hancock and Letitia Fairbanks, The Fourth Musketeer, (New York: Henry Holt and Company, 1953), 196.
} 
castle. $^{26}$ The effort was called "Fairbanks' most ambitious undertaking," using one million feet of lumber, twenty thousand yards of velvet, and ten thousand extras. ${ }^{27}$

In an attempt to garner publicity around the film, Fairbanks welcomed thousands of tourists onto the set to watch the elaborate battle scenes from constructed grandstands overlooking the set. Together, he and Pickford welcomed special guests for luncheons in the castle set's grand hall and constructed a strategic road-showing exhibition strategy that would debut first in major cities, as well as some cities within England and France. With the exception of a humorous anecdote of a publicity stunt gone wrong from the roof of the Ritz Hotel, wherein Fairbanks, displaying his archery skills to a group of reporters, accidentally pierced a man through the backside in a building two blocks away, the publicity campaign surrounding this film is primarily remembered as culminating with the very first "Hollywood red carpet premiere." ${ }^{28}$ At the Egyptian Theatre in Los Angeles, where the film was to run for a subsequent successful six months, the film premiered on October 19, 1922, where a consortium of film stars, press, and fans alike gathered to celebrate the film's opening. ${ }^{29}$ Red carpet premieres today remain an essential part of a film's publicity, offering a symbiotic relationship between the press and the filmmakers with the intention to generate positive word-of-mouth and attract attention to the film in question.

\footnotetext{
${ }^{26}$ Dan Kiernan "Fairbanks scored the first hit with epic 1922 Robin Hood," The Globe and Mail (Canada). June 7, 1991.

27 "DOUGLAS FAIRBANKS IN ROBIN HOOD - "Greatest Filmshow on Earth" Robin Hood Program, 1922, page 2, Douglas Fairbanks Papers, Box 5, folder 3, Margaret Herrick Library.

${ }^{28}$ Robin Hood Program, 1981, page 7, Douglas Fairbanks Papers, Box 5, folder 4. Margaret Herrick Library.

${ }^{29}$ See Haberkamp, Program from Douglas Fairbanks in Robin Hood on Monday, June 27, 2011, 4.
} 
Robin Hood would go on to be a substantial commercial success, earning $\$ 2.5$ million and garnering over 100,000 tickets sold in New York alone. ${ }^{30}$ It was just one of many period-set adventure films Fairbanks would make for UA, including The Mark of Zorro (Niblo, 1920), The Three Musketeers (Niblo, 1921), The Thief of Bagdad (Walsh, 1924), and The Black Pirate (Parker, 1926), all of which are the apogee examples of blockbusters due to their basis on well known, pre-existing properties, genre-based marketing and release strategies, and grandiose spectacle. Robin Hood's release is chronologically situated in the middle of these landmark features, having been the highest grossing film in Fairbanks' UA oeuvre, as well what biographers Ralph Hancock and

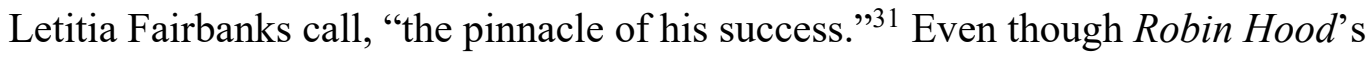
achievements would be unmatched by any future projects Fairbanks embarked upon in his career, both The Thief of Bagdad and The Black Pirate are noteworthy in the particular ways in which they furthered the blockbuster model.

Accordingly, The Thief of Bagdad relies heavily upon visual trickery and special effects in order to build the world of larger-than-life characters and magical beings within its universe. The film was critically polarizing, some considering the display of Fairbanks' acrobatics and technical effects overused and garish, while others were astounded that the film made the impossible seem real..$^{32}$ A review from the New York Times embodied both perspectives, dismissing the narrative construction of the film as merely, "an Arabian Nights satire," but hailing the visual splendor of the film as featuring

\footnotetext{
${ }^{30}$ Kiernan, "Fairbanks scored first hit with epic 1922 Robin Hood," 1991.

${ }^{31}$ Hancock and Fairbanks, The Fourth Musketeer, 201.

${ }^{32}$ See Richard Schickel, His Picture in the Papers (New York: Charterhouse Publishers) 1974, 81-88.
} 
"wonderfully well-worked-out double exposure photographic effects, and even to an experienced eye the illusion is in nearly every instance kept up to a state of perfection." ${ }^{\prime 3}$ The universal acknowledgement of the film's spectacle is complemented by its marketing emphases. This can be no more clearly seen than in an original program for the film in 1924, wherein a full-page spread is dedicated simply to talking points the filmmakers wish to leave with the viewer, entitled, "A few things to puzzle about after you have seen The Thief of Bagdad." Included on the list are items such as "The Flight of a Thousand Steps leading to the Citadel of the Moon," "the Winged Horse that carries the thief in spectacular flight through space," and "the Magic Carpet of Bagdad which bears its owner over the housetops and away into the Land of Romance." Finally, the list encourages the viewer to ponder over the "scores of other features that render this glorious fantasy of ancient Bagdad the most enthralling spectacle ever brought to the screen. ${ }^{34}$ In this way, Spectacle and Salability are interconnected and symbiotic, the film's advertising not only emphasizing the sheer scale of the film's spectacle, but also demonstrating how the film's marketing used some of the feature's most grandiose thrills in order to generate positive word-of-mouth and numerous repeat viewings.

So attuned was Fairbanks to the susceptibility of his UA films' progress and success that he strove to remain relevant by concerning himself with the rapidly changing technologies of the film industry at the time, embracing new two-color Technicolor

33 “The Screen," New York Times, March 19, 1924.

34 The Thief of Bagdad Program, 1924, 16, Margaret Herrick Library, The Thief of Bagdad Press Materials. 
technology in The Black Pirate, that featured two tones instead of the later three. ${ }^{35}$ Said Fairbanks, "Pirates demand color. Stories of modern life [...] might be told in black and white, but what pirates needed was something more vivid." ${ }^{\prime 6}$ Fairbanks served only as the producer and star of the film, yet the specific hues of color used were completely of his own design, adjusted to suit different lighting conditions on set. ${ }^{37}$ Consequently, The Black Pirate is remembered as one of the first attempts to prominently feature the new Technicolor process. ${ }^{38}$ The showcasing of technological innovations remains key to many Hollywood blockbusters, as a display of new technological innovations, a cutting-edge entry into the world of "new" or "never before seen" techniques can therein serve as selling points to attract viewers, further rendering the film as a must-see event. ${ }^{39}$

Through genre, choice of literary material, publicity, the embracing of new technology, and simply the man himself, Fairbanks serves as the single most emblematic founder of the blockbuster model. His films became central to his lasting public image as a thrill-seeking everyman, one which biographer Tracey Goessel observes as later even influencing the comic book iconography of both Superman and Batman. ${ }^{40}$ Most biographical profiles center on his seemingly fairytale "rags-to-riches" life story, indelible work ethic, and role both in UA and as the first president of the Academy. What

\footnotetext{
${ }^{35}$ The Catalina Island Museum Society Presents The Black Pirate: A silent film classic, program, Santa Catalina Island, May 281989 at the Avalon Theater, 2, The Black Pirate Press Material, Margaret Herrick Library.

${ }^{36}$ John C. Tibetts and James M. Welsh, His Majesty the American: The Cinema of Douglas Fairbanks, Sr, (New York: A.S. Barnes and Company, 1977), 148.

${ }^{37}$ The Catalina Island The Black Pirate program, 2.

${ }^{38}$ Tibetts and Welsh, His Majesty the American, 149.

${ }^{39}$ Michael Allen, "Talking about a revolution: the blockbuster as industrial advertisement," in Movie Blockbusters, ed. Julian Stringer, (New York: Routledge, 2003), 101.

${ }^{40}$ Tracey Goessel, The First King of Hollywood: The Life of Douglas Fairbanks, 225.
} 
merits further attention is a comprehensive analysis on Fairbanks' action hero persona, treated as the bulk of his contributions rather than merely an aftereffect of his other contributions to the cinematic medium. Only through such a study would it be possible to more accurately compare his stardom to that of his founding counterparts Mary Pickford and Charlie Chaplin, the personae of which have been heavily analyzed and documented.

\section{Charlie Chaplin: Stardom \& Spectacle}

Charlie Chaplin's foremost contribution to the blockbuster model can be found in Stardom and Spectacle. Similar to Fairbanks, Chaplin wielded these criteria in order to heighten his own larger-than-life persona, though he ultimately produced half as many pictures as Fairbanks during his time at UA. Upon the formation of the company, each of the four artists agreed to a preliminary contract to produce nine pictures within the proceeding five years (1919-1924). ${ }^{41}$ Griffith, Pickford, and Fairbanks each delivered on this agreement: Chaplin generated but one. In fairness, Chaplin, with lingering contractual obligations to First National Film Company, finally began to deliver on these obligations four years after the rest of the artists. However, he was never able to overcome the impact of the delay, which is significant when juxtaposed with the sum total of the productions of the other founders: Pickford, twenty-six; Fairbanks, sixteen; Griffith, sixteen; Chaplin, eight.

Chaplin was known to be a perfectionist who agonized over every aesthetic element of his pictures. He is the only one of the founders to have written, directed, produced, and acted in each of the films he made for UA. His first release was $A$ Woman of Paris in 1923, a full four years after the company was formed, and it severely

${ }^{41}$ Balio, United Artists: The Company Built by the Stars, 28. 
underperformed at the box office. According to Chaplin himself in his autobiography, this film was "the first of the silent films to articulate irony and psychology" which critics believed could not be conveyed without the many nuances of spoken language. ${ }^{42}$ However, Balio rather attributes the film's failure to its antipodal standing apart from the rest of Chaplin's typical oeuvre in two main ways: 1) the film was a drama, not a comedy and 2) Chaplin appeared solely in an uncredited bit, instead giving the picture to Edna Purviance as the main star. ${ }^{43}$ Though Chaplin was an extremely popular, international celebrity of mass public and critical acclaim, the salability of his film output stemmed directly from his "Tramp" persona and resulting comedy films. Chaplin was more attached than his fellow founders to the notion of UA operating as a wholly independent distribution company, in service to the release of his films under his own authority. This granted him the sole creative autonomy he craved in order to make personal, passion projects rather than studio-controlled content driven for profit. ${ }^{44}$ Yet both Chaplin and Griffith quickly discovered the public's lukewarm or completely ambivalent responses to these sorts of productions (e.g. A Woman of Paris). Chaplin quickly made the correction, and returned back to making Tramp-centered films, whereas Griffith never found popular support again for the remainder of his career.

Chaplin's ability to garner widespread attention through his character of the Tramp speaks volumes about the power of the character's constructed persona. The Tramp is an amalgamation of emotion and comedy, making him an endearing figure first

${ }^{42}$ Charlie Chaplin, My Autobiography (Melville House Publishing: London, 1964), 294295.

${ }^{43}$ Ibid., 45.

${ }^{44}$ Balio, United Artists: The Company Built by the Stars, 74. 
before presenting his mischievous side. ${ }^{45}$ His films often contain themes pertaining to social issues or human strife. For example, in the formative era of UA, particular projects reflected several key themes: heartbreak and failure in The Gold Rush, love despite adversity in City Lights (Chaplin, 1931), and the threats of an industrialized society in Modern Times (Chaplin, 1936). David Robinson refers to Chaplin's Tramp persona as a perfect blend between comedy and sentimentality, able to express intense emotions including grief, sadness, or loss, but balancing it with genuine comedy. ${ }^{46}$ Although ultimately Chaplin would step away from the Tramp and perform as other characters in his final two films for UA Monsieur Verdoux (Chaplin, 1947) and The Limelight (Chaplin, 1952), it is the Tramp he is most remembered for.

What distinguishes the work of Chaplin from that of Pickford and Fairbanks is his embracing of a singular character amidst differing scenarios, whereas the latter two portrayed varied characters of a certain "type" throughout their respective oeuvres. Furthermore, Chaplin was rarely beholden to a script, preferring to improvise aspects of the narrative as filming commenced. ${ }^{47}$ This, when paired with his complete creative control over all aspects of his films, resulted in a more creative, spectacle-based production process. His following two films after $A$ Woman of Paris, The Gold Rush (Chaplin, 1925) and The Circus (Chaplin, 1928), not only feature the Tramp in his trademark comedic, over-the-top situations, but also happen to be two of his most technically impressive films. The Gold Rush featured many such sequences, notably the

\footnotetext{
${ }^{45}$ Pamela Hutchinson, "Charlie Chaplin and the Tramp: the birth of a hero," The Guardian, January 27, 2014.

${ }^{46}$ Ibid.

${ }^{47}$ Chaplin, My Autobiography, 298.
} 
film's expository opening scene, which employed hundreds of extras ascending in a single-file line up a snowy mountain pass on location in the Sierra Nevada Mountains. Also noteworthy is the climatic sequence where the Tramp's house teeters and falls from the edge of a cliffside, featuring both large mechanical rigs and lifelike models to complete the visual illusion. The Circus similarly employed hundreds of extras, featured death-defying stunts, and included live animals, which memorably included a troop of monkeys that attacked an already tight-rope walking Tramp above a large group of spectators. Though The Circus was plagued with production troubles, including a fire that had completely destroyed the set, both it and The Gold Rush were extremely popular with audiences and, according to Robinson, the latter film is that which Chaplin most wished to be remembered for its sheer amount of creativity in its making. ${ }^{48}$

As Chaplin's focus was first and foremost on his own artistry, his UA contract accordingly had specific clauses within ensuring complete creative autonomy over his work through every level of production. This included the stipulation that no changes to the film of any kind, including title cards, could occur without his express approval. ${ }^{49} \mathrm{In}$ addition, Chaplin retained control over all advertising pertaining to his films, including art and print materials associated with marketing the product. This also included "chief prominence," which meant that his name would appear in letters at least twice the size of any other part of the subject matter in which his name appeared.$^{50}$ By comparison, Mary Pickford's contract contained both of the same clauses, however, the means in which

\footnotetext{
${ }^{48}$ David Robinson, Charlie Chaplin: Comic Genius (New York: Harry N. Abrams, Inc. 1996), 60.

${ }^{49}$ UA Memorandum of Agreement, page 9, 2/5/1919, Charles Chaplin Contract, folder 1, Margaret Herrick Library.

${ }^{50}$ Ibid., 7.
} 
Pickford and Chaplin demonstrated their business and marketing tactics could not have been more different when it came to the internal operations of UA as a whole. The construction of star personae through on-screen imagery such as this was in both Chaplin's and Pickford's contract verbiage, although in general their business and marketing tactics were divergent in nature. Similarly, Chaplin and Griffith contrasted in their approach to filmmaking - whereby Chaplin strove to contain his artistic and character-focused films, Griffith's aesthetic vision for his films fluctuated between uncontained spectacle and intimate dramas.

\section{D.W. Griffith: Show \& Spectacle}

Although one would think that D.W. Griffith would be the most emblematic of the blockbuster model, as he is credited as having made the "first" blockbuster, The Birth of a Nation, in actuality, D.W. Griffith is the only of the four UA members whose body of work produced for UA remains the least influential to the blockbuster model. ${ }^{51}$ Throughout his UA oeuvre, he vacillated between producing the intimate dramas he aspired to create independently and being forced to produce larger films more synonymous with his prior epics that were sure to please audiences and garner a profit. His sole consistent contribution to the blockbuster model during his history with UA is in Show, crafting the moviegoing experience of his films into a must-see entertainment

\footnotetext{
${ }^{51}$ Stringer, Movie Blockbusters (New York: Routledge, 2003), 7. The Birth of a Nation is now considered an ideologically racist film that has been analyzed for its highly problematic messages, themes, and portrayals in works such as Brian Gallagher's 1982 article "Racist Ideology and Black Abnormality in the Birth of a Nation" (Phylon 43:1) or Melvyn Stokes' 2008 book D.W. Griffith's The Birth of a Nation: A History of "The Most Controversial Motion Picture of All Time" (Oxford University Press). This thesis cites this film only within the context of its widespread popularity at the time of its release and its aesthetic importance to the foundation of the Hollywood blockbuster model.
} 
event. His first release for UA (only the second motion picture release in the company's history) was Broken Blossoms (1919), which marked a turning point in Griffith's onceprosperous career even though it performed well both financially and critically. ${ }^{52}$ Once fully integrated with UA, his producing tastes veered sharply from his methods of the past; what began as spectacular epics shifted to literary-based melodramas, marking a return to the style of his early short subject that thereby rendered him "out of touch" with his public. ${ }^{53}$ Miriam Hansen credits this shift in public taste with the disintegration of the "film as universal-language metaphor" that Griffith and other early film pioneers fervently embraced. ${ }^{54}$ The onset of World War I decreased the circulation of film product between countries, inciting what Hansen calls the "Americanization of the cinema" 55 where narrative-centric films ultimately evolved to appease the mass, consumer culture created by the increased development and utilization of theater houses ${ }^{56}$ As a result, Griffith's emphasis on visual symbolism and artistry started to lose momentum with the changing times.

Broken Blossoms otherwise remains an intimately shot character drama, and lacks the spectacle synonymous with the blockbuster model. The film nevertheless holds

${ }^{52}$ See Eileen Bowser's note (page 6) in a Broken Blossoms program from the Los Angeles International Film Exposition in Culver City, California on Wednesday April 19, 1978. Bowser contrasts Broken Blossoms to Griffith's previous work, calling it "a smallscale, studio-made film, a gentle fairy tale of nonresistance to violence." She further notes that it would be the last time Griffith would experience widespread critical success. Broken Blossoms Production Files, Margaret Herrick Library.

${ }^{53}$ Richard Schickel, D.W. Griffith: An American Life, (New York: Simon \& Schuster, Inc., 1984), 425.

${ }^{54}$ Miriam Hansen, Babel \& Babylon: Spectactorship in American Silent Film, (Cambridge: Harvard University Press, 1991), 78-82.

${ }^{55}$ Ibid. 79

${ }^{56}$ Ibid. 84-85. 
extreme value and important placement in establishing a marketing precedent for a Broadway-competitive, cinemagoing event that is essential to the blockbuster model. UA capitalized on Griffith's well-established brand and marketed Broken Blossoms as an event of true, artistic merit. The film premiere at the George M. Cohan Theatre in New York City featured an admission price of $\$ 3.00$, rivaling prices of Broadway theatrical productions.$^{57}$ The original program from this event featured a page wherein statements from initial reviews were curated beneath the title "New Photographic Inventions." There the Morning Telegraph compared the resulting effects to that of a "beautiful painting," while the New-York Tribune seemed at a loss for words: "It was soft and lazy and blue and roseate — but what is the use—words can't tell anything about the picture." 58 These factors likened Broken Blossoms to both the fine and performing arts, something which would follow the film throughout its run far beyond its initial premiere.

When the film debuted at the Illinois Theater in Chicago in 1919, a critic praised Griffith, calling him "a class all by himself" and suggested that his skill was unrivaled amongst filmmakers of the day. The critic described the theater itself as being "touched by a discerning wand," its interior transformed by warm lighting, burning incense, flower adornments, and ushers in the form of performers who were dressed like "beautiful houris ${ }^{59}$ in the shimmer raiment of the orient. ${ }^{960}$ Over half the review is devoted to the

\footnotetext{
${ }^{57}$ Hall and Neale, Epics, Spectacles and Blockbusters, 44.

${ }^{58}$ Program from the original Broken Blossoms premiere at the George M. Cohan, New York City, New York, May 13, 1919, 6. Broken Blossoms Production Files, Margaret Herrick Library.

${ }^{59}$ The word houri is defined according to Encyclopedia Britannica as a group of angelic women who "await the devout Muslim in paradise," though it remains unclear what relevance costuming ushers as Muslim religious figures has preceding a film screening about a Chinese immigrant. "Houri," Encyclopedia Britannica. ${ }^{60}$ Ibid.
} 
theatrical experience of screening the film within the theater house and the showmanship present, leaving minimal analysis of the film itself. The sole criticism of the picture comes at the expense of the elements of Spectacle, where the action is called "too slow. It takes you a long while to get into the story." ${ }^{11}$ In both instances of the film's respective premieres, the film itself was auxiliary to the extratextual elements that made the film a must-see experience, as emphasized by both critics and UA themselves.

In contrast, the UA film that most exemplifies Griffith's foundational contributions to the blockbuster model is Way Down East (1920), as it is the only film during this phase of his career to satisfy all four required categories of the blockbuster model. Like The Birth of a Nation, Way Down East was epic in length, consisting of twelve-reels, twice as long as most films produced in that era. Its opening night premiere in New York City's Forty-fourth Street Theatre saw a dramatic record-breaking admission price of ten dollars per orchestra-level seat. ${ }^{62}$ Way Down East marked Griffith's thirty-eighth project with star Lillian Gish, their lifelong collaboration serving as a staple to Griffith's overall brand. Most of the poster and print advertising released for Way Down East prominently features Gish's likeness, her name appearing in similar size and scale to that of Griffith's. Griffith incorporated elements of the spectacular in utilizing the latest color printing tinting and toning process, Prizmacolor, the precursor to Technicolor. ${ }^{63}$ This, accompanied with the film's climatic final action sequence filmed on

\footnotetext{
${ }^{61}$ Mae Tinée, "Again Mr. Griffith Shows 'Em How It Should Be Done," The Chicago Tribute Review for Broken Blossoms, 1919. New York Public Library, Lillian Gish Papers. 62 "\$10 To See Griffith Film,” New York Times, August 28, 1920. Accessed January 25, 2019.

${ }^{63}$ Hall and Neale, Epics, Spectacles and Blockbusters, 65.
} 
location at a massive waterfall in White River Junction, Vermont, served as marketable features, said scene making up the majority of the poster and print ad imagery.

In one advertisement for Way Down East entitled, "How Did Griffith Do It," (which never fully answers that question) a New York audience screening the film was so enveloped in the action, that they leapt "to [their] feet." ${ }^{64}$ In spite of this thrilling finale, the film otherwise remains a fairly straightforward drama, shot mostly with interior scenes between a small cast. This becomes reflective of Griffith's work under UA as a whole, for as his career was drawing to a close (his last film The Struggle being released through the company in 1931), his lavish degree of visual spectacle, set dressings and effects never rivaled that of his pre-UA oeuvre. Griffith's most significant contribution to the blockbuster, by these examples, is in Show, as the production value, grandeur, running time, and focus on visual aesthetics and the depiction of human emotion renders his UA films more akin to an art exhibit or a Broadway show. As films became symbols of modernity, such associations would prove alienating to an industry engaged in furthering the elements of the spectacular he once dominated.

Despite this ultimate fall from mainstream popularity, Griffith's name and reputation as a star in his own right was by far the foremost selling point of his films. From the hundreds of short silent pictures he produced at the start of his career with the Biograph Company to the record-breaking success of his later epic features, Griffith joined UA as an already established film icon, or as one journalist put it, "Beyond all

64 "How Did Griffith Do It?" 1920, Lillian Gish Papers, Box: Series X, Photographs. New York Public Library. Performing Arts Research Collection. 
doubt the biggest name in filmdom!" 65 It is here necessary to create a distinction in star personae between that of a director and an actor. Griffith's name gained repute only through products he delivered from behind the camera and his ability to both attract and influence a large audience. Similar to contemporary Hollywood, a film's association with a notable and recognizable auteur predetermines its quality because of previous acclaim. A wholly different association arises from actors, however, as the presentation of their characters both on and off screen defined their star personae. Such can be seen with Fairbanks, Chaplin, and Pickford, all of whom were stars, writers, directors, and producers of their work for UA, and all of whom experimented with their star brand image to varying degrees of success. However, Mary Pickford exemplifies a synergy between marketing tactics and her star personae. Mary Pickford: Salability \& Stardom

Mary Pickford carefully curated her star persona, be it through her physical appearance, the roles she took on, the products she endorsed, or the people with whom she associated. "America's Sweetheart," "Queen of Movies," "The Girl with the Golden Curls; " Pickford was known by all of these monikers and as one of the most famous actresses of her time. Similarly, her keen perception of business was undeniable and has been noted by a variety of scholars, ${ }^{66}$ as well as Chaplin himself, who said, "I was astonished at the legal and business acumen of Mary. She knew all the nomenclature [...]

${ }^{65}$ D.W. Griffith Papers, Microfiche Reel 4. Mark Vance, "D.W. Griffith - The Greatest of Them All" 5/20/1919, 813. Museum of Modern Art.

${ }^{66}$ See Balio, United Artists: The Company Built by the Stars. 
On these occasions she saddened me more than amazed me, for this was an aspect of 'America's Sweetheart' that I did not know."67

Like her three male counterparts, the creative autonomy Pickford received through founding UA allowed her the opportunity to break free of the limitations imposed by the rival studios. Pickford's earliest success was with Tess of the Storm Country (Porter 1914), which resultantly led to her typecasting in "little girl roles" in other massive hits such as Pollyanna (Powell, 1920), M'Liss (Neilan, Green, 1918), and The Poor Little Rich Girl (Tourneur, 1917). ${ }^{68}$ These roles not only perpetuated an innocent and wholesome persona, something that further became associated with her pristine ringlet curls, but also became a major component of the recognizability of her image. ${ }^{69}$ In fact, so important was this image to the public that whenever she attempted to break free of the "little girl" role, these films saw less financial and critical success with both critics and viewers. Writes Christel Schmidt in her chapter "Crown of Glory: The Rise and Fall of the Mary Pickford Curls" that "so identified was Little Mary with her golden ringlets that when she donned a dark, heavy wig in films such as Hearts Adrift (Porter, 1914), Little Pal (Kirkwood, 1915), and Madame Butterfly (Olcott, 1915), writers and critics took note with more than a hint of disappointment." ${ }^{.70}$ Gaylyn Studlar argues that when Pickford made radical attempts to differentiate herself from this typecasting,

${ }^{67}$ Robert Cushman, "Putting it Together: How the Mary Pickford Collection Came to the Academy Library," in Mary Pickford Rediscovered, ed. Kevin Brownlow, (New York City: Harry N. Abrams, Inc., 1998), 42.

${ }^{68}$ Gaylyn Studlar, "Oh 'Doll Divine': Mary Pickford, Masquerade, and the Pedophilic Gaze." Camera Obscura, 48, Volume 16, Number 3 (1996): 199.

${ }^{69}$ Christel Schmidt, "Crown of Glory: The Rise and Fall of the Mary Pickford Curls." In Mary Pickford, Queen of the Movies, ed. Christel Schmidt. (Kentucky: The University Press of Kentucky, 2012), 172.

${ }^{70}$ Ibid. 
the public had difficulties separating her star persona from the characters she played. ${ }^{71}$ This allowed the little girl roles Pickford played to shape the course of her professional career in that this innocent image was so widely embraced that the public "disavowed her status as a woman." 72 Pickford used this autonomy to free herself from her previously established public image of the early 1910s, yet her difficulty in doing so is reflected in the trajectory of her filmography. Towards the latter half of her career, Pickford increasingly made efforts to evolve her "girl" persona to that of a woman in adult roles, as illustrated in UA's My Best Girl (Taylor, 1927), The Taming of the Shrew (Taylor, 1929), and Coquette (Taylor, 1929), Pickford's first film after receiving her controversial bobbed haircut that was a contested matter among her large fan base. ${ }^{73}$ These more mature films were still popular with audiences, Coquette even garnering $\$ 300,000$ more than any other Pickford picture despite three thousand of the theaters UA distributed to not being able to show it due to insufficient sound wiring. ${ }^{74}$ Coquette's success demarcates an interconnectedness between the Salability of the narrative being adapted from a popular Broadway play, the Spectacle surrounding the film being Pickford's first talkie, and the maturation of her persona as a whole.

Pickford's first attempt to break free of the "little girl" image accompanied the production of Rosita (Lubitsch, 1923). Pickford of course starred in the titular role, one which garnered her a significant amount of critical and public praise. ${ }^{75}$ This film made a

\footnotetext{
${ }^{71}$ Studlar, “Oh 'Doll Divine,"” 202.

72 Ibid.

73 Schmidt, "Crown of Glory," 183.

${ }^{74}$ Kevin Brownlow, "Rosita" in Mary Pickford Rediscovered, ed. Kevin Brownlow, (New York City: Harry N. Abrams, Inc., 1998), 232.

75 Ibid. 197-198.
} 
high gross of just over one million dollars at the box office, ${ }^{76}$ and existed on a scale that would be the closest to a contemporary blockbuster in accordance with my established definition, including hundreds of extras and a large production design scale.

Advertisements, posters, and prints from the film show Pickford ornately dressed in full costume, her curly hair, though tied up, still elaborately styled to emphasize its trademark appearance. On the available posters and print materials from the Pickford collection, her name looms larger than all other names present, if any at all. Pickford's name and image are at the forefront of the marketing, which lies in accordance with her role as the primary power behind the production [Appendix C].

For Rosita, Pickford personally hired renowned German director Ernst Lubitsch, as well as the crew that ultimately constructed an elaborate set for Seville built on the Pickford-Fairbanks studio lot that featured hundreds of extras. Pickford famously bickered with Lubitsch on set and was generally displeased with the final product despite its success and did not permit the preservation of any existing negatives during her lifetime. ${ }^{77}$ From elements of pre-production, production, post-production, and ultimately preservation, it was Pickford who had the final word in how Rosita was created and distributed. Her name, image, and power of selection all worked in tandem to build up her brand and market this film as a uniquely Pickford product, and further, by the tenets of the blockbuster, was a highly salable display of her star persona.

\footnotetext{
76 This total gross figure, according to the US Inflation Calculator, would amount to $\$ 14.7$ million today.

${ }^{77}$ Brownlow, "Rosita," 200.
} 


\section{$\underline{\text { Conclusion }}$}

UA's first twelve years marked a formative period wherein all four original artists were producing content concurrently. Accordingly, 1928 and 1929 were the most economically prosperous years in the UA's history before the era of management by Arthur Krim and Robert S. Benjamin, each year garnering over twelve million dollars domestically. ${ }^{78}$ These years were not only the final two economically stable years leading up to the Great Depression, but also notably marked a time in which all four founding artists were producing content regularly and simultaneously. Such success was achieved by the artists' adapting their works into popular commodities in order to ensure overall salability within a distribution system that was not guaranteed to garner a profit. In so doing, they employed practices that innovated the contemporary Hollywood blockbuster.

On March 24, 1928, Exhibitors Herald and Motion Picture World published a $10^{\text {th }}$ anniversary retrospective about UA and its progression in Hollywood thus far with a headline that read rather judgmentally, "United Artists Stars $10^{\text {th }}$ Year with Only 75 Films Made." The article analyzes the content that had been produced by UA up to that time, noting that while thirty-six had been original pieces, twenty-nine were based on novels and short stories, nine from plays, and one from a song. ${ }^{79}$ This amounts to more than half of the UA productions being based on previously existing (and therefore more salable) content. ${ }^{80}$ The article intends to point out the stagnancy of UA, undercutting its

\footnotetext{
${ }^{78}$ Balio, United Artists: The Company Built by the Stars, Appendix 4, 283. 79 "United Artists Stars 10th Year with Only 75 Films Made" Exhibitors Herald and Motion Picture World, Chicago, 3/24/1928. Mary Pickford Papers, United Artists 19241961, box 179, folder 1825. Margaret Herrick Library.

${ }^{80}$ Though certainly sometimes an original product, a blockbuster is often based on a preexisting property, sometimes referred to as "pre-sold." This includes films based on wellknown books, comics, songs, television shows, true stories, but also encompasses sequels
} 
achievements by comparing its output to that of the other major Hollywood studios, who by that point were all vertically integrated and embracing block booking practices. In comparison, a rival major studio would have produced UA's seventy-five film sum within but a few years. In 1926, for example, MGM alone saw its most profitable season with the release of forty-four films in a single year. ${ }^{81}$ Arguably, UA's separation from the block-booking system enabled them to be highly selective in their output, choosing products that were recognizable, salable, and therefore profitable; all of which are cautious measures ensuring their corporation's potential for longevity.

Despite this separation, UA did not remain wholly "independent" in all senses of the term throughout the studio system era. In 1924, Joseph Schenck was brought on as chairman of the board UA in light of the company's mounting debt. Part of his plans for reorganization included the creation of the United Artists Theatre Circuit, a series of firstrun theater houses in densely-populated areas where UA product would be guaranteed exhibition and financial returns. ${ }^{82}$ Although this marked a turn toward major studio vertical integration processes of the major studios, it further marked a continued effort to keep the company separate and competitive with them as well. Moreover, in 1941 Pickford, Chaplin and several other United Artists members including David O. Selznick, Sam Goldwyn, Orson Welles, and Walt Disney formed the Society of Independent

(franchises), remakes, and reboots. If we were to take domestic gross statistics to prove this point, the top highest grossing films of 2018 (all of which also happen to fall under the established blockbuster model as well) were all based on pre-existing properties: five came from comic book basis, nine were sequels and/or part of a larger franchise, and one was a remake based on a book.

${ }^{81}$ Thomas Schatz, The Genius of the System, (New York: Pantheon Books) 1988, 39.

${ }^{82}$ Balio, United Artists: The Company Built by the Stars, 64. 
Motion Picture Producers in order to advocate for the rights of independent producers. ${ }^{83}$ The formation of this group was one of many actions leading up to the ultimate Paramount Decision of 1948, wherein the branches of production were divested and UA's new distribution tactics under Krim and Benjamin would, as Balio attests, set the standard for how Hollywood cinema is developed and distributed in America today. ${ }^{84}$ These actions laid the groundwork for independently produced films to achieve blockbuster status with major studio distribution, such as The Godfather (Coppola, 1972) and Star Wars (Lucas, 1977).

As the first major independent studio, UA's formation is at the heart of discourse about the roles of both art and commerce that continues to this day. In journalism and critical studies today, blockbusters are consistently dismissed by critics. Julian Stringer writes, "Films labeled as blockbusters are frequently positioned as examples of the culturally retrograde, beneath serious consideration or analysis." ${ }^{\circ 5}$ The 2018 announcement and immediate retraction of the inclusion of the Best Popular Film category at the Academy Awards called into question the legitimacy of Hollywood blockbuster cinema on an international scale, as such a category complicated and blurred the distinction between the Academy-hailed highbrow (art) films and otherwise neglected lowbrow (commercial) films within Hollywood filmmaking. ${ }^{86}$ Despite this discord, this

\footnotetext{
83 Ibid. 226

${ }^{84}$ Balio, United Artists: The Company That Changed the Film Industry, 6. ${ }^{85}$ Stringer, "Introduction," 1.

${ }^{86}$ See Gillian Roberts, "Circulations of Taste: Titanic, the Oscars, and the middlebrow" in Movie Blockbusters, ed. ed. Julian Stringer (New York: Routledge, 2003), 155-166. Roberts attributes the Academy's role in the film industry to be that of a "standard setter," and specifically credits Titanic (Cameron 1997) as having been first film in decades to transcend the polarity between art and commerce through its Academy wins, leading the way for future Best Picture-winner Gladiator (Scott 2000). Since the time of
} 
proposed addition has reignited an ongoing debate about the role of Hollywood film as a commercial or artistic medium, comparing the practices and cultural significance of the blockbuster with that of arthouse cinema. ${ }^{87}$ This thesis has argued that it is the joint stardom, innovative spirit, and essential need to produce competitive content that the founders of UA presented that established the blockbuster that exists today, blurring the distinctions between arthouse and commercial cinema: Independent cinema embraces both arthouse and blockbuster films alike, and has since UA's founding 1919.

UA's four core founders Mary Pickford, Charlie Chaplin, Douglas Fairbanks, and D.W. Griffith, through both their joint collaboration in the company and individual talents, introduced practices that embody the central tenets of this blockbuster model. From marketing authority to spectacular visual imagery, death-defying thrills and turning moviegoing into a significant event, these four artists can be credited as the first to establish the blockbuster phenomenon in order to differentiate themselves and remain competitive within the larger studio system. This thesis therein legitimizes blockbuster filmmaking as a significant practice that has been the cornerstone of the Hollywood film industry for over a century.

the writing of this piece, there has been but one Best Picture-winning blockbuster (according to the presented blockbuster model) that have mirrored these successes - The Lord of the Rings: Return of the King (Jackson 2003).

87 Tatiana Siegel and Gregg Kilday, "Academy Creates More Problems Than It Solves With 'Popular' Oscar," The Hollywood Reporter, August 2018. Accessed September 14, 2018. 
Appendix A

\section{The Blockbuster Model*}

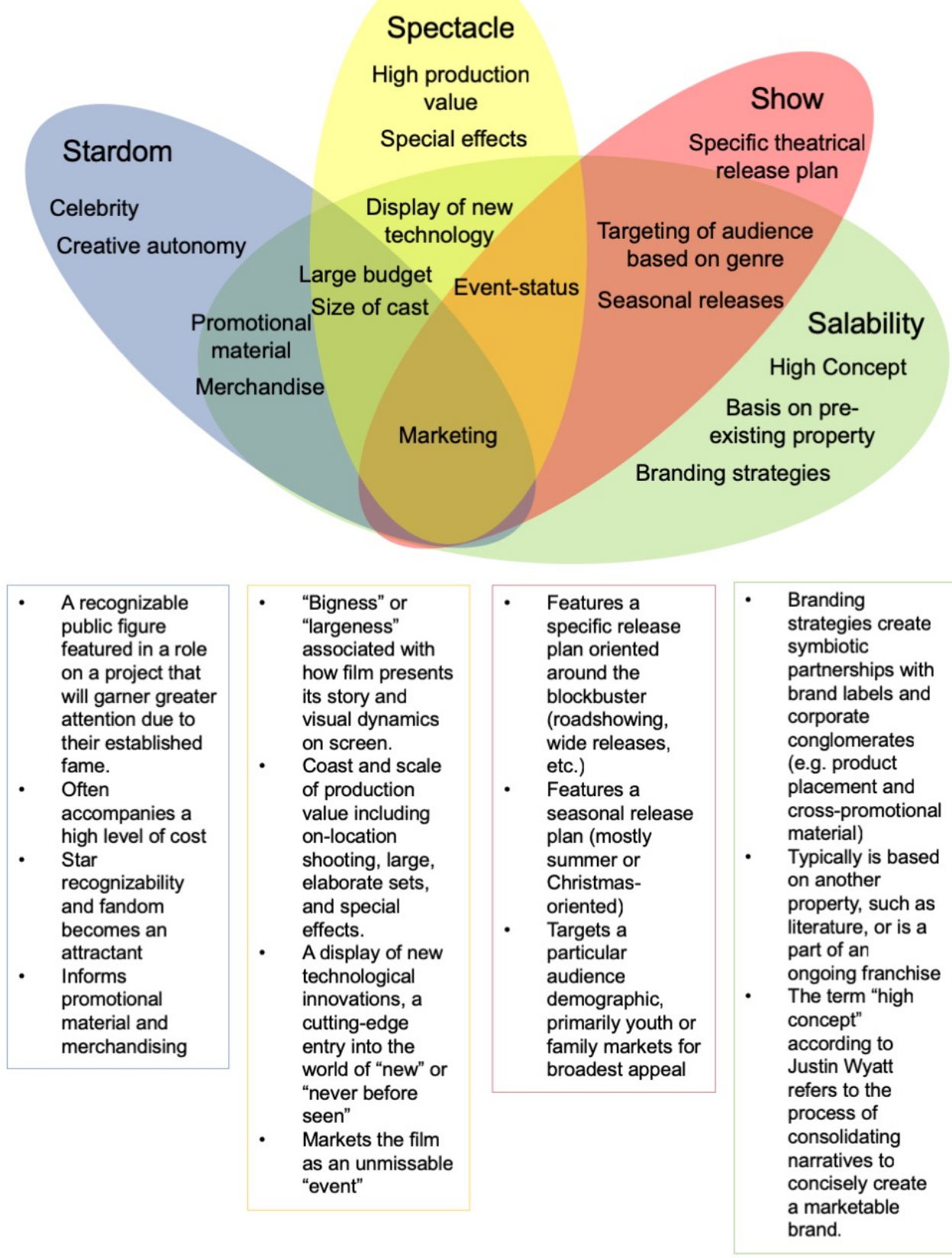

*For blockbuster consideration, a film must display compliance with each of the four categories, regardless of overlapping or shared criteria. 


\section{Appendix B}

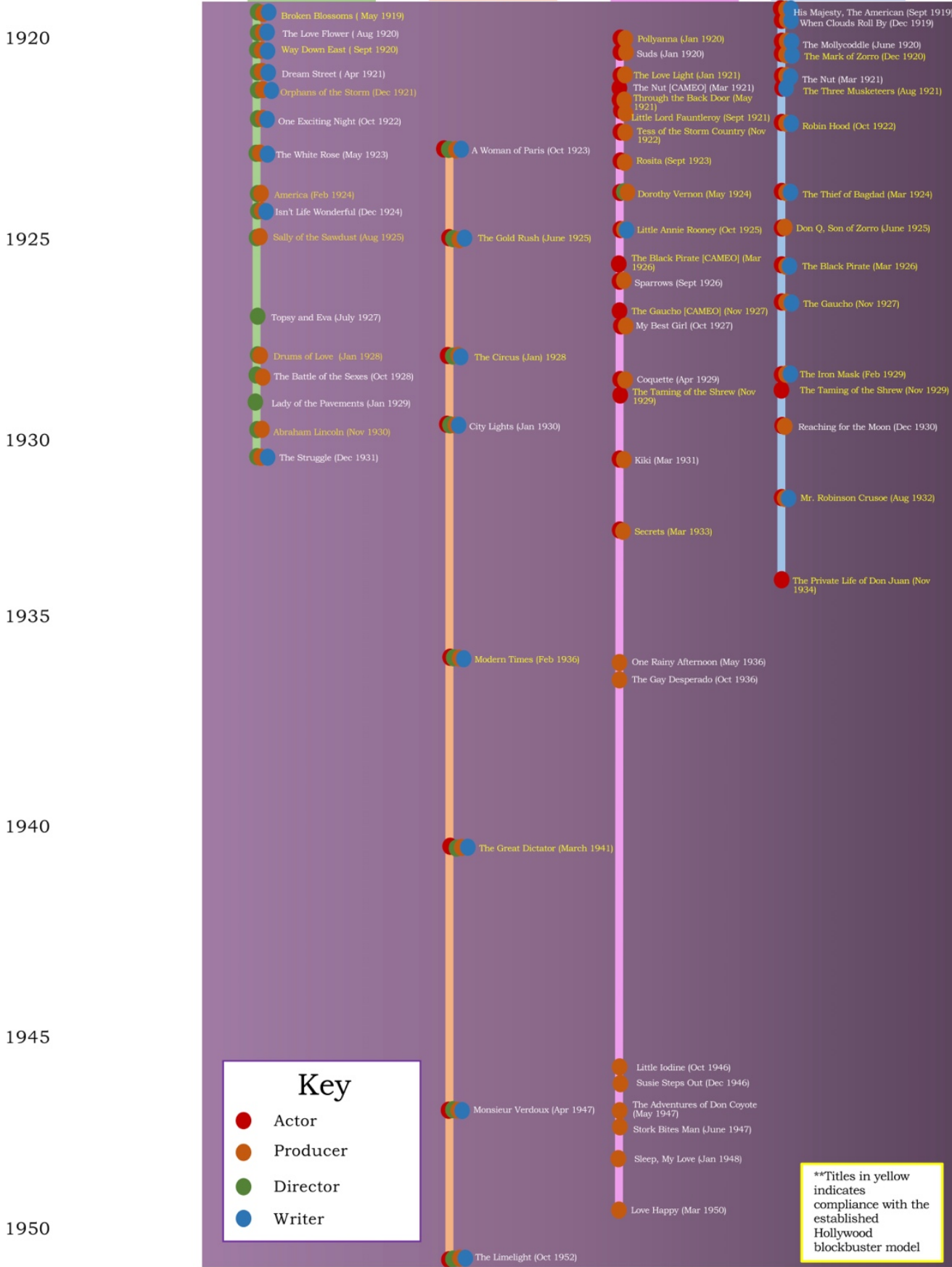

Graph of UA Founder's Film Projects and Roles, J. Johnson 2019 
Appendix C

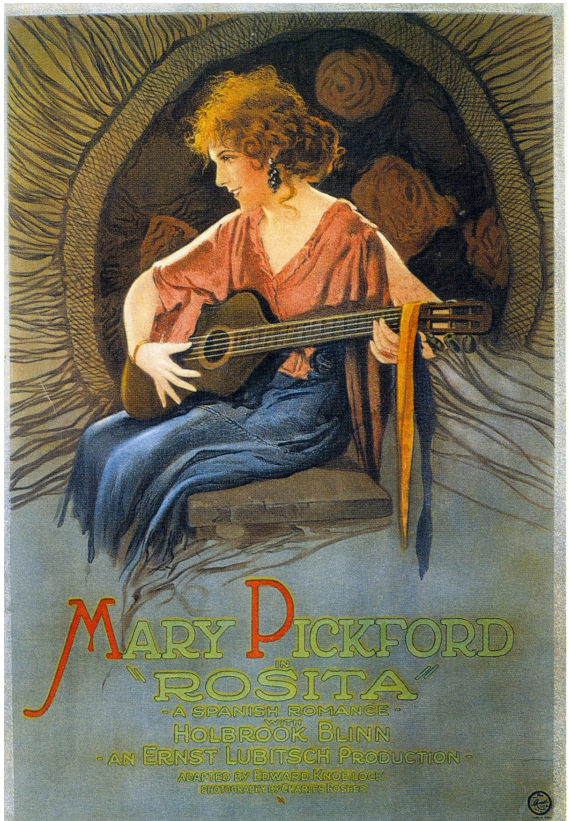

Poster for Rosita (Lubitsch, 1929). Courtesy of the Mary Pickford Foundation

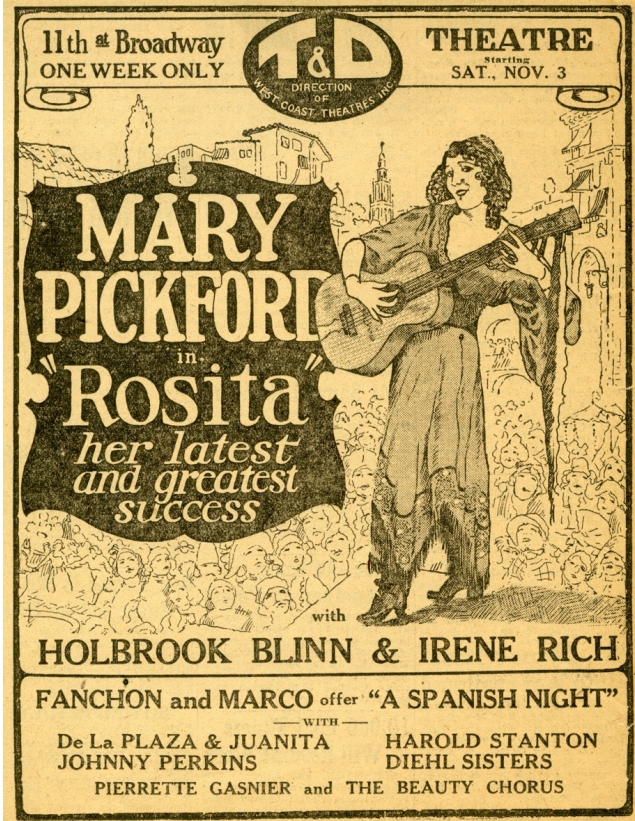

Print ad for Rosita (Lubitsch, 1929). Courtesy of the Mary Pickford Foundation 


\section{BIBLIOGRAPHY}

Primary Sources:

The Black Pirate Press Material, The Catalina Island Museum Society Presents The Black Pirate: A silent film classic, program, Santa Catalina Island, May 281989 at the Avalon Theater, 2, Margaret Herrick Library.

Broken Blossoms Production Files, Program from the original Broken Blossoms premiere at the George M. Cohan, New York City, New York, May 13, 1919. Margaret Herrick Library.

Charles Chaplin Contract, folder 1, Margaret Herrick Library.

Douglas Fairbanks in Robin Hood Production Files, Randy Haberkamp. Program from Academy of Motion Picture Arts and Sciences screening of Douglas Fairbanks in Robin Hood on Monday, June 27, 2011 at the Samuel Goldwyn Theater, Margaret Herrick Library.

Douglas Fairbanks Papers. Margaret Herrick Library, Beverly Hills, California.

D.W. Griffith Papers. Museum of Modern Art, Manhattan, New York.

Lillian Gish Papers, Performing Arts Research Collection. New York Public Library, Manhattan, New York. 
Mary Pickford Papers, Margaret Herrick Library, Beverly Hills.

Mary Pickford and United Artists Corporation Legal Material [1919-1972]. Margaret Herrick Library, Beverly Hills, California.

The Three Musketeers Production Files, Oversized red striped press book, Margaret Herrick Library.

Secondary Sources

“\$10 To See Griffith Film,” New York Times, August 28, 1920. Accessed January 25, 2019.

Acland, Charles R. "Senses of Success and the Rise of the Blockbuster." Film History: An International Journal 25, no. 1-2 (2013): 11-18.

Allen, Michael. "Talking About a Revolution: The blockbuster as industrial advertisement.” In Movie Blockbusters, edited by Julian Stringer. New York: Routledge, 2003.

Balio, Tino. United Artists: The Company Built by the Stars. Wisconsin: The University of Wisconsin Press, 1976. 
Balio, Tino. United Artists: The Company that Changed the Film Industry. Wisconsin, The University of Wisconsin Press, 1987.

Bordwell, David. “1919: Hollywood’s Boom Year,” New York Times, Feb. 5, 2019, Opinion.

Brownlow, Kevin. Mary Pickford Rediscovered: Rare Pictures of a Hollywood Legend. New York: Harry N. Abrams, Academy of Motion Picture Arts and Sciences, 1999.

Chaplin, Charlie. My Autobiography. London: Melville House Publishing: London, 1964.

Cushman, Robert. "Putting it Together: How the Mary Pickford Collection Came to the Academy Library.” In Mary Pickford Rediscovered, ed. Kevin Brownlow. New York City: Harry N. Abrams, Inc., 1998.

Elberse, Anita. Blockbusters: Hit-Making, Risk-Taking, and the Big Business of Entertainment. New York: Henry Holy and Company Publishers, 2013.

Elsaesser, Thomas. The Persistence of Hollywood. New York: Routledge, 2012.

Goessel, Tracey. The First King of Hollywood: The Life of Douglas Fairbanks. Chicago: Chicago Review Press, 2015. 
Gomery, Douglas. “The Hollywood blockbuster: industrial analysis and practice.” In Movie Blockbusters, edited by Julian Stringer. New York: Routledge, 2003.

Grainge, Paul. Brand Hollywood: Selling entertainment in a global media age, London: Routledge, 2008.

Hall, Stuart and Steve Neale. Epics, Spectacles and Blockbusters, Detroit: Wayne State University Press, 2010.

Hancock, Ralph and Letitia Fairbanks. The Fourth Musketeer. New York: Henry Holt and Company, 1953.

Hansen, Miriam. Babel \& Babylon: Spectactorship in American Silent Film. Cambridge: Harvard University Press, 1991.

Hutchinson, Pamela. "Charlie Chaplin and the Tramp: the birth of a hero," The Guardian, January 27, 2014. Accessed March 12, 2019.

Kiernan, Dan. "Fairbanks scored the first hit with epic 1922 Robin Hood." The Globe and Mail (Canada). June 7, 1991. 
King, Geoff. "Spectacle, Narrative, and the Spectacular Hollywood Blockbuster." In Movie Blockbusters, edited by Julian Stringer. New York: Routledge, 2003.

King, Geoff. Spectacular Narratives: Hollywood in the Age of the Blockbuster. New York: Tauris Publishers, 2000.

Naremore, James. More than Night: Film Noir in Its Contexts. Berkeley: University of California Press, 2008.

Neale, Steve. Genre and Hollywood. London: Routledge, 2000.

Neale, Steve. "Hollywood Blockbusters: Historical dimensions" In Movie Blockbusters, edited by Julian Stringer. New York: Routledge, 2003.

Rehak, Bob. '2003: Movies, 'Shock and Awe,' and the Troubled Blockbuster,” In American Cinema of the 2000s: Themes and Variations, edited by Timothy Corrigan. New Brunswick: Rutgers University Press, 2012.

The Return of the Epic Film: Genre, Aesthetics and History in the Twenty-first Century. Edited by Andrew B.R. Elliott. Edinburgh: Edinburgh University Press Ltd, 2014.

Roberts, Gillian. "Circulations of Taste: Titanic, the Oscars, and the middlebrow," in Movie Blockbusters. Edited by Julian Stringer, New York: Routledge, 2003. 
Robinson, David. Charlie Chaplin: Comic Genius. New York: Harry N. Abrams, Inc., 1996.

Robinson, David. Chaplin: His Life and Art. New York: Da Capo Press, 1994.

Schatz, Thomas.The Genius of the System. New York: Pantheon Books, 1988.

Schatz, Thomas. "The New Hollywood." In Movie Blockbusters, edited by Julian Stringer. New York: Routledge, 2003.

Schickel, Richard. D.W. Griffith: An American Life. New York: Simon \& Schuster, Inc., 1984.

Schickel, Richard. His Picture in the Papers. New York: Charterhouse Publishers, 1974.

Schmidt, Christel. "Crown of Glory: The Rise and Fall of the Mary Pickford Curls." In Mary Pickford, Queen of the Movies, edited by Christel Schmidt. Kentucky: The University Press of Kentucky, 2012.

“The Screen,” New York Times, March 19, 1924. Accessed April 1, 2019.

Shone, Tom. Blockbuster: How Hollywood Learned to Stop Worrying and Love the Summer. New York: Free Press, 2004. 
Siegel, Tatiana and Gregg Kilday. "Academy Creates More Problems Than It Solves With 'Popular' Oscar,” The Hollywood Reporter, August 2018, Accessed September 14, 2018.

Stringer, Julian. Movie Blockbusters. New York: Routledge, 2003.

Studlar, Gaylyn. “Oh 'Doll Divine': Mary Pickford, Masquerade, and the Pedophilic Gaze." Camera Obscura, 48, Volume 16, Number 3, 1996.

John C. Tibetts and James M. Welsh, His Majesty the American: The Cinema of Douglas Fairbanks, Sr., New York: A.S. Barnes and Company,1977.

Wyatt, Justin. High Concept: Movies and Marketing in Hollywood. Austin: University of Texas Press, 1994. 